\title{
ETHNOMYCOLOGICAL KNOWLEDGE AND NUTRITIONAL ANALYSIS OF SOME WILD EDIBLE MUSHROOMS OF SAGARMATHA NATIONAL PARK (SNP), NEPAL
}

\author{
A. Giri and P. Rana
}

\begin{abstract}
This paper describes the traditional mycological knowledge of Sherpa community of Sagarmatha National Park (SNP) and its adjoining areas (2600-4000 masl). Twenty nine species were identified having ethnomycological use. Among which 26 were identified as edible, 2 as medicine and 1 for decorative purposes. The local communities are well familiar about the morphological feature, habitat and qualities of these mushrooms. The local names of mushrooms have been derived on the basis of their morphological features, nature of growth and colour. The indexes of similarity of edible mushrooms along different forest range from $40-80 \%$. Proximate composition (moisture, ash carbohydrate, crude fat, crude protein and crude fibre) and mineral composition (calcium, phosphorous and iron) of 11 most prized edible mushrooms was investigated. The overall nutritional values of wild edible mushrooms analyzed were good and comparable to other cultivated varieties of mushrooms.
\end{abstract}

Key words: Ethnomycology, edible, mushrooms, nutrition, protein

\section{Introduction}

Wild edible mushrooms are one of the important natural resources on which the local people of all nationalities rely heavily, and these mushrooms certainly play a role in improving the food nutrition (Yang, 2002). Edible mushrooms contain high level of dietary fiber, substantial amount of protein, vitamins and minerals but are low in fat. They also have various properties for health benefits such as antioxidative, antitumour and hypercholesterolic effects (Wong and Cheung, 2001).

In context to Nepal, ethno mycological studies have been conducted by various researchers (Sacherer 1979; Bhandary 1985, 1991, 1992; Cotter and Miller 1987; Kharel and Rajbhandary 2005; Adhikari et al. 2005; Giri and Rana 2005, 2006 and 2007; Pandey 2006. Similarly, the nutritive value of wild edible mushrooms of Nepal was analyzed by Singh and Nisha (1973), Adhikari et al. (1996) and Pandey and Budathoki (2007a and 2007b). However, information on documentation of indigenous knowledge of mushrooms is limited and poor. The present study was undertaken to document the use of wild edible mushrooms and to analyze the nutritive value of prized edible mushrooms identified with the help of Sherpa community residing within the study area.

\section{Study area}

The study area lies in Solu-Khumbu district of the northeastern region of Nepal. It encompasses the Sagarmatha National Park (1,148 sq. km) and its buffer zone area (Figure 1). The park 
includes the upper catchments areas of the Dudh Kosi and Bhote Kosi rivers. The park is largely composed of the rugged terrain and gorges of the high Himalayas ranging from 2845 meter above sea level (masl.) at Monju to the top of the world Sagarmatha (Mount Everest) at 8848 masl.

The summer climate is cool and wet while the winter is cold and dry. Almost all the annual precipitation, averaging less than $1,000 \mathrm{~mm}$ falls during the summer monsoon, from the end of May to September. During winter (December to February) the day time temperature often falls below $0^{\circ} \mathrm{C}$ and there is heavy snow fall.

The park contains 3\% forest, $28 \%$ grazing land and $69 \%$ barren land above the tree line. The dominant vegetation at the lower elevation of the park below 3000 masl is composed mostly of blue pine and hemlock forest. The lower sub alpine region (above 3000 masl.) comprises of forests of Pinus walliaichana, Abies spectabilis and Juniperus recurva. The upper subalpine region, (above 3600 masl.) consists of birch - rhododendron forest (Betula utilis, Rhododendron campanulatum and $R$. campylocarpum) and the lower alpine region above the timber-line at 3800 - 4000 masl. houses scrubs (Juniperus spp., R. anthopogan and $R$. lepidotum).

The park is populated by approximately 3,000 of the famed Sherpa people. The main settlements are Namche Bazar, Khumjung, Khunde, Thame, Tengboche, Pangboche and Phortse. The economy of the Sherpa community has traditionally been agriculture, animal husbandry and trade with Tibet.

\section{Methodology}

\section{Collection}

During the field survey, a total of 200 respondents within the age of 10-70 years were interviewed by applying artifact and inventory interviewing methods (Nepal et al., 1999) and semi structured questionnaire. The ethnomycologically important mushrooms identified by the locals were collected from Lukla (2,800 masl.) to Pangboche $(4,000$ masl.) during the month of August to September 2006 (Fig 1). The fully matured mushroom species were collected from different parts of the study area by uprooting its substratum with the aid of a scalpel or sharp knife. The collected mushroom specimens were photographed in their natural habitat before they were picked up. Data on habit and habitat such as ecological parameters such as altitude, forest type, etc. were recorded in the field. Each collection was placed in butter paper bags and tag numbers were assigned to them. Morphological characters and chemicals test were performed in the field. The specimens were either sun dried or dried by placing them on tin foil over a local oven. Each dried mushrooms specimens were placed in separate butter paper bags. The specimens were identified in the laboratory with the help of standard literatures (Adhikari, 2000; Imazaki , 1979; Purukayastha and Chandra, 1985; Svreck, 1975; McKenny, 1971; Mcknight \& Mcknight, 1987) and studying the macroscopic and microscopic characters. The specimens were housed in Nepal Academy of Science and Technology. 


\section{Nutritional analysis}

Taxonomically and locally identified as prized wild edible mushrooms were collected, shed dried and further subjected to nutritional analysis. Proximate analysis (moisture, carbohydrate, crude protein, crude fat, crude fiber, moisture and ash) was performed at the Department of Food Technology and Quality Control (DFTQC) in accordance with the official methods of Analysis of the Association of Official Analytical Chemist (AOAC, 1995). All the calculations were carried out on dry weight basis of mushrooms. The minerals such as phosphorous $(\mathrm{P})$, calcium (Ca) and iron (Fe) was read on Atomic Absorption Spectrophotometer (AAS).

\section{Results and Discussion}

Twenty nine ethnomycologically important mushrooms were identified with the help of Sherpa community residing within the study area, Among them 26 species of mushrooms were used for edible, 2 species for medicinal and one for decorative purpose.

According to respondents the most prized edible mushrooms in that region were Amanita hemibapha (Berk. \& Br.) Sacc., Boletus edulis Bull.: Fr., Boletus auripes Peck, Cantharella cibarius (Fr..: Fr.) Fr., Chroogomphus tomentosus (Murr.) O.K. Miller, Gomphus clavatus (Pers.: Fr.) S. F. Gray, Gomphus floccosus (Schw.) Sing. var. floccosus, Hydnum repandum L.: Fr., Ramaria flava (Sch.: Fr.) Quel., Leccinum sp. (local name: Petok), Hygrophorous sp, Paxillus involutus (Batsch: Fr.) Fr. Among them the bigger/tastier/ abundant/ species were more popular and consumed by the locals. Species like Amanita vaginata (Bull.: Fr.) Vitt., Auricularia polytricha (Mont.) Sacc., Boletus pulverulentus Opat., Clavulina cinerea (Bull.: Fr.) Schroet., Russula metachroa Hongo, Hypholoma capnoides (Fr.) Kumm., Rhodocollybia butyraceae (Bull.: Fr) Lennox, Armillaria mellea (Vahl.: Fr.) Kummer, Laccaria laccata (Scop.: Fr.) Cooke may have been less popular due to their smaller size/less abundance.

Below Namche the local people hardly preserve mushrooms for culinary uses.

This may be due to availability of the variety of vegetables in this region as compared

to the upper high altitude region. Field survey reveals that a superstition "storing mushrooms results in the death of their livestock" still prevails among some Sherpas of lower region (Lukla, Benkar, etc.).

In the higher region (Khumjung, Khunde) dried mushrooms were found to be sold at 50 rupees per "mana" (locally used measurement approx. $30 \mathrm{gm}$ in one mana) irrespective of the variety. According to locals the rainy season (July to September) is the favorable time for the collection of wild edible mushroom. Some local people above Namche believe that they should not initiate new work (business) or engage in agricultural work during the month of Shrawan (July - August). During this period locals are found to be engaged in collecting and drying wild edible mushrooms from nearby forests. The local who goes early gets a good collection of mushrooms. In Namche economically sound people hired local people to collect mushrooms; labor collectors earn around Rs. 100-500 per day according to the amount and variety of mushroom species.

According to the respondents the frequency and diversity of fructification of mushrooms depends upon various factors such as temperature, percentage of rainfall, humidity, etc. in a 
particular season. Most of the respondents believe that due to prolonged snow fall the snow remains longer on the ground resulting in better growth of mushrooms. The indexes of similarity of edible mushroom species along different forests range from $40-80 \%$. This analytical result suggests that different forests have got more than $60 \%$ similar edible mushroom species. This is because of altitudinal levels that have got more or less similar climate, rainfall, temperature and vegetation.

\section{Local Nomenclatural Practices for Mushrooms}

The local inhabitants have accumulated a large quantity of traditional knowledge and experience in utilization of the wild edible mushroom resources. They are well familiar about the morphological features, habitats, qualities of various edible mushrooms. Mushrooms are called "Shyamo" in Sherpa which means cap. In Nepali it is known as "Chyau". The local name of the wild edible mushrooms has been mostly derived on the basis of their morphological features, nature of growth, colour, etc. Gomphus clavatus is known as "Eeshyamo" (Eng: mother-in-law) in Sherpa dialect. The name of this mushroom is derived from its growth characteristic. As the mother-in-law plays a dominant role in the family this mushrooms grows dominantly (about 5-7 kg) in one place. Since Gomphus floccosus looks like a burning "Diyo" (Eng: oil lamp) it is called "Diyo chyau" or "Khumbhe chyau". Clavulina cinerea, Ramaria flava and Ramaria botrytis are known as "Che shyamo" due to its grass like appearance. Hydnum repandum is locally named as "La shyamo" (Eng: musk deer) or "Kasturi chyau" due to its resemblance to the skin of musk deer. Amanita spp. which have an egg like volva are known as "Anda (Eng: egg) chyau" Further depending on its size or colour of the cap a prefix may be added such as "sano" (small), "rato" (red), "seto" (white), etc. Amanita hemibapha is known as "Rato anda chyau", Amanita vaginata as "Seto anda chyau", Amanita sp. as "Sano anda chyau" due to its red coloured, white coloured and small cap respectively. Boletus sp. locally called as "Fhe (Eng: mouse) shyamo" got its name due to it's resembles with a mouse hiding in the forest. Boletus edulis is known as "Pani (Eng: water) chyau". Armillaria mellea is known as "Chiple" (Eng: sticky) chyau because of its sticky honey like cap surface. Hypholoma capnoides locally known as "Taktale" which means growing in layers one above the other in a bunch. Auricularia polytricha locally know as "Durkha chyau" as it is chewed as Durka (Eng.: hard cheese). Leccinum sp. is known as "Petok" which means beautiful in Sherpa dialect. Hygrophorous sp. is locally known as "Omi (Eng: milk) shyamo" or "Dudh (Eng:milk) chyau" due to its milky appearance. Cantharellus cibarius is known as "Kujir (pothi)" and Chroogomphus tomentosus is known as "Kujir (keta) in Sherpa dialect. Kujir reflects acidic yellow or dull yellow colour. Further depending on size and colour they distinguish "Kujir" as "Pothi" (female) and "Keta" (male). In their view" Kujir pothi" is bigger and brighter coloured than "Kujir keta". Tylopilus eximus is known as" Khyakti" (Eng: bitter) in Sherpa dialect due to its bitter taste. It was observed that locals prefer to collect the pileus than the stipe for the culinary purpose. According to them the pileus is less bitter than the stipe. Rhodocollybia butyraceae is known as "Pothi karshya" ( karshya : white) in Sherpa dialect due to its white appearance. Lycorperdon perlatum is known as "Phusphuse" because when pressed its powdery spore eject out slowly making a phus-phus sound. Ganoderma sp. is known as "Chhale (Eng: skin) chyau" because its outer layer resembles thick skin. It 
was also observed that the local people have adopted both Sherpa as well as Nepali names for the mushrooms (Table 1).

\section{Method for Preparation of Mushroom Food}

The general method used for the preparation of the edible mushrooms comprises the following steps. After collection the mushrooms are thoroughly washed and diced and then boiled with Zanthoxylum armatum (timur) and Allium sativum (lasun). After which the water is drained off and the mushrooms are cooked according to their desire (fried or soup) and seasoned with timur, garlic, hotchilli etc. Mushroom such as Gomphus clavatus, Leccinum sp. and Hygrophorus sp. are specially used to prepare the filling of Momo (Dumplings). Pickle is prepared by mixing Zanthoxylum armatum, salt and hotchilli along with a little amount of oil and this mixture is put in glass or plastic bottle which is placed in the sun. The favorite mushrooms used by the locals to prepare pickle are Gomphus clavatus, Ramaria flava, Paxillus involutus, Leccinum sp. etc. In Khunde, Auricularia polytricha (Mont.) which grows on Rhododendron trees are allowed to dry in the tree till winter after which they are chewed raw as hard cheese. The common method observed for preserving mushrooms is sun drying.

\section{Medicinal Mushrooms}

In addition to food item mushroom is also used in health treatment by the rural people. According to some local informants spores of Lycoperdon perlatum Pers.:Pers. and $L$. pyriforme Schaeff.:Pers. are used as powder to heal wounds and to cure baby rashes. Hobbs (1987) reported several species of Lycoperdon to be used to stop bleeding in a fresh wound. Similar results were reported by Adhikari (1988), Bhandary (1991) and Ghimire et al. (2001) from eastern and western regions of Nepal. Joshi and Joshi (1999) reported that the aerial parts of $L$. pyriforme are used as tonic in case of weakness by the locals residing in Pokhara. Sharma (2003) reported that spores of $L$. pyriforme are used by people from Jammu to arrest the flow of blood from the wounds and in the treatment of piles. Some locals use mushrooms like Ganoderma sp. for decorative purposes while some polypores are used to make lids of bottle and stop cork. This was also reported by Kharel (1998) and Adhikari (2000). In this study it was observed that mushrooms were not used for religious or ceremonial purposes.

In the Nepalese mycoflora there are at least forty species of mushrooms which have been known to be toxic and dangerous. There is always the risk of eating a poisonous species mistaking it to be an edible one. In Nepal the mortality rate due to consumption of poisonous mushrooms have been found to occur around 15-20 persons annually (Adhikari, 2004). As per interviews with local people, hospital staff and traditional healers no mushroom poisoning cases were reported till date in the study area. It was observed that local people boil mushrooms along with Allium sativum and zanthoxylum armatum and discard the broth to minimize the possible poisoning from mushrooms. Whereas, in central Nepal and western Nepal people break the fruit bodies, smell and taste to find out whether mushroom are poisonous or not. People of that region used Paris poryphylla (Satuwa), Zanthoxylum armatum, Allium sativum to minimize possible poisonous along with vinegar (Adhikai et al., 
2005). Besides this, the local people aged between 10-70 years easily distinguish the poisonous mushrooms from edible ones on the basis of knowledge handed down from generations. Apart from edible mushrooms they consider other mushrooms as poisonous. This may be a way to safeguard the younger generation from eating poisonous mushrooms. The poisonous mushrooms are referred to as "bhoot chyau" in Nepali dialect and "Sindi shyamo" in Sherpa dialect. However, some local people even believe that "Mushrooms become poisonous only after being bitten by a poisonous snake." Therefore, in their view the mushrooms are not that poisonous because there are no poisonous snakes in that region. According to local informants they use Aconitum sp. (Bikhma) to minimize the effects of food poisoning.

In Khumbu region the Sherpa people do not sacrifice or kill animals. Meat is very expensive and rarely eaten item. It is only available in the weekly hart bazaar and is brought all the way from Jiri by carrying it in a "doko" (bamboo woven basket). Therefore, the people of higher region rely on seasonal mushrooms as a major source of protein substitute to meat. Mushrooms have good nutritional value particularly as a source of protein that can enrich human diet especially in developing countries where animal protein may not be available and are expensive (Pandey and Budathoki, 2007a).

\section{Nutritive Values of Mushrooms}

Out of 26 wild edible mushrooms (Giri and Rana, 2007) proximate chemical analyses were concentrated in eleven wild edible mushroom species. Mushrooms were selected on the basis of region-wise availability and popularity among local residents of the study area.

The selected edible mushrooms were Ramaria flava (Schaeff.: Fr.) Quel., Paxillus involutus (Batsch : Fr.), Gomphus clavatus (Pers.: Fr.), Leccinum sp., Ramaria botrytis (Pers.: Fr.) Ricken, Hygrophorous sp., Gomphus floccosus (Schw.) Singer, Tylopilus eximus (Perk) Sing., Chroogomphus tomentosus (Murr.) O.K.Miller, Amanita hemibapha (Berk. \& Br.) Sacc., Boletus $\mathrm{sp}$. During analysis nine parameters such as crude protein (\%), crude fat (\%), crude fibre $(\%)$, moisture (\%), carbohydrate (\%), calcium ( $\mathrm{mg} / 100 \mathrm{~g})$, Phosphorous (mg/100g), iron ( $\mathrm{mg} /$ $100 \mathrm{~g}$ ) of mushroom samples were carried out.

The chemical composition of edible mushrooms determines their nutritional value. It differs according to species but also depends on the substratum, atmospheric conditions, age and part of the fructification (Manzi et al., 2001). The average crude protein content of edible mushrooms ranges between 19-40\% (Kurtzman, 1978). Chroogomphus tomentosus (11.84\%) had the lowest value while Ramaria flava (28.32\%) had the highest value. Mushrooms like Ramaria flava (28.32\%), Gomphus clavatus (22.68\%), Hygroporous sp (22.97\%). Amanita hemibapha (25.87\%), Gomphus flocosus (20.97\%) and Tylopilus eximus (25.89\%) have protein content comparable to commonly cultivated mushrooms in Nepal such as Agaricus bisporous (26.3\%) and Volvariella volvacea (29.5\%). These mushrooms have higher protein content than Lentinula edodes (17.5\%) and Pleurotus ostreatus (10.5\%) (Table 4).

The average range of carbohydrate content in edible mushrooms varies from 27.6 to $71.1 \%$ of dry wt (Rautaavara, 1947 cited by Purkayastha and Chandra 1985). In the present study the 
values of carbohydrates range from a low of 31.02\% in Amanita hemibapha on a dry weight basis to a high of $62.63 \%$ for Chroogomphus tomentosus. The crude fat content of mushrooms is $2-8 \%$ of the dry weight but it can vary from less than $1 \%$ to as high as $15-20 \%$ (Crisan and Sands, 1978). The lowest crude fat constituent was found in Amanita hemibapha (0.39\%) and the highest value was observed in Ramaria botrytis (28.32\%). The moisture content in dry mushroom ranges from 10-12\% (Crisan and Sands, 1978). The moisture in eleven samples of mushroom varied from the lowest value of $8.30 \%$ in Gomphus floccosus to the highest of $11.95 \%$ in Hygrophorous sp. Crisan and Sands (1978) stated that fibre content in mushrooms is very high and varies from $3-33 \%$. In the present study Hygrophorous sp. (7.73\%) had the lowest fibre content while Tylopilus eximus $(19.84 \%$.) had the highest value (Table 2). The calcium content in eleven samples of mushroom varied from $1.82 \mathrm{mg} / 100 \mathrm{gm}$ (Boletus sp.) to $33.09 \mathrm{mg} / 100 \mathrm{gm}$ (Gomphus floccosus). The quantity of phosphorous was lowest in Ramaria flava $(62.51 \mathrm{mg} / 100 \mathrm{gm})$ while Paxillus involutus $(944 \mathrm{mg} / 100 \mathrm{gm}$.) had the highest calcium content. Leccinum sp. $(0.576 \mathrm{mg} / 100 \mathrm{gm})$ had the lowest iron content while the Amanita hemibapha (307.26 mg/100 gm) had the highest calcium content (Table 3 ). The range of calcium, phosphorous and iron content in most of the studied wild edible mushroom are comparable to some cultivated mushrooms like Agaricus bisporous, Pleurotus ostrateus, etc, (Table 4).

The chemical composition (crude protein, carbohydrate, crude fat, crude fibre, iron, calcium and phosphorous) of mushroom samples were comparable to the range given by Crisan and Sands (1978). Most of the mushrooms are comparable with the cultivated common edible mushrooms such as Pleurotus ostreatus, Volvariella volvacea, Agaricus bisporus and Lentinula edodes (Table 4).

\section{Conclusion}

This study further helps to contribute for the document of the use of mushroom resources found in the study area. The results of this study underscore the need to conduct a nationwide survey on the indigenous uses of mushrooms to safe guard the knowledge handed down from generations.

Mushrooms have been considered as ultimate health food (Rai, 1995). In the era of healthy eating it is bound to attract attention as they possess unique chemical composition. However, research on the nutrition and evaluation of wild edible mushrooms and chemical analysis of medically important wild mushrooms is scanty in Nepal. Therefore, major emphasis has to be given to conduct intensive research in this field which would further enable us to utilize important mushrooms to the benefit of the people and nation.

Basically in Nepal research has been concentrated in pre-commercial experimentation of commercially important edible mushrooms such as Pleurotus ostreatus, Volvariella volvacea, Agaricus bisporus and Lentinula edodes, etc. However, focus has not yet been centered on the potential wild edible mushrooms. Government and private institutions should promote and undertake research to develop cultivation practices of the wild edible mushrooms which have good nutrient value and are prized by the locals. 
Forest is the suitable habitat for mushrooms, but destruction of the forest and degradation of the forest resources have had an adverse impact on the existence of mushrooms and other plant resources. The local people in the study area collect these prized edible mushrooms from different forests localities haphazardly. Very few efforts have been taken into consideration to manage and protect the fungal diversity and their habitat. Moreover, the local people have been experiencing decline of some edible mushrooms within the study area (Rana and Giri, 2006). Unmanaged harvesting and climate change could be a contributing factor for this decline. In order to ensure continued production of these wild edible mushrooms from their natural habitat effective conservation methods and proper harvesting techniques is recommended.

\section{Acknowledgements}

We are grateful to Prof. Dr. H.N. Bhattarai, Vice chancellor and Prof. Dr. D. Subba Secretary, of NAST for their kind support. We express our profound gratitude to Ev-K2-CNR, Italy for the financial support. Our special appreciation goes to the Warden, staff and people of Sagarmatha National Park (SNP). We would like to thank Mr. Pragun S. Sainju for assisting us during our field work.

\section{References}

Adhikari, M.K. (1988). Some higher fungi from Langtang and its adjoining area. In: Proceedings of National Conference on Science and Technology organized by Royal Nepal Academy of Science and Technology (RONAST), Kathmandu:237-241

Adhikari, M.K. and Durrieu, G. (1996). Ethnoimycologie Nepalaise Bull. Soc. Myc.

France, 113:31-41.

Adhikari, M. K.; Adhikari, K.S.; Joshi, A.R.; Bhandary, R. C.; Gyawali, M. B. and Pradhan, B. (1996). Studies on food value and mycotoxic wild mushrooms of Nepal. Submitted to APINMAP/SCAPMAP/UNESCO committee of Nepal, Ministry of education, Nepal. p. 92.

Adhikari, M.K. (2000). Mushrooms of Nepal. PU Printers, Batisputali, Kathmandu, Nepal: 236.

Adhikari, M.K. (2004). Mushroom poisoning and its state in Nepal. Plant Resources Bulletin No.25. Department of Plant Resources Kathmandu, Nepal:56-58.

Adhikari, M. K., Devkota, S. and Tiwari, R.D. (2005). Ethnomycological knowledge and uses of wild mushrooms in western and central Nepal. Our Nature, 3:13-19.

AOAC (1995). Official Methods of Analysis: Association of official Analytical Chemists 16th E.d., Arlington, VA.

Bhandary, H.R. (1985). Mushrooms. In: Nepal Nature's Paradise (Ed.Majpuria, T. C) Craftman press, Bangkok, Thailand.

Bhandary, H.R. (1991). Some edible and medicinal fungi from Dumre to Manang, Mustang and Pokhara. Journal of Natural History Museum, 12(1-4):47-60.

Crisan, E.V. and Sands, A. (1978). Nutritional value. In: The biology and cultivation of edible 
mushrooms (Eds. S.T. Chang and W.A. Hayes). Academic Press Inc. London: 137-168.

Cotter, H.V.T. and Miller, O.K (1987). Ectomycorrhizal association of the Bolete genus Suillius in Nepal. In: Proceeding of Seventh North American conference in mycorrhizae, Ganeaville, FI.U.SA: 5.

Ghimire, S. K.; Lama, Y.C.; Tripathi, C. R.; Schmitt, S. and Thomos, Y. A. (2001). Conservation of plant resources, community development and training in applied ethnobotany at SheyPhoksundo National Park and its buffer zone, Dolpo. Final report, WWF Nepal program and people and park initiative, Kathmandu, Nepal.

Giri, A. and Rana, P. (2005). Study of Mushroom Diversity and its Economic Value in Sagarmatha National Park. A Report submitted to Evk2-CNR, Italy and NAST, Nepal.

Giri, A. and Rana, P. (2007). Some Wild Edible Mushrooms Recorded from High Altitude Eastern Nepal. Food Wave, 4:1-6.

Hobbs, C. (1987). Medical mushrooms. Botanica press, Box 742 Capitola, Ca 95010.

Imazeki, R.; Otani, Y. and Hongo, T. (1979). Coloured illustration of fungi of Japan. 1 \& 2. Hoi Usha Co. Ltd., Japan

Joshi, K. and Joshi, A. R. (1999). Ethnobotanical study of some wild mushrooms of two valleys (Kathmandu and Pokhara) of Nepal. Ethnobotany, 11:47-56.

Kharel, S. (1998). Ethnomycological study on wild edible mushrooms of Bhardeo VDC Lalitpur Nepal [M.Sc thesis]. Central Dept Botany, Tribhuvan University:155.

Kharel. S. and Rajbhandary, S. (2005). Ethnomycological knowledge of some wild edible mushrooms in Bhardeo, Lalitpur, Nepal. Nepal Journal of Plant Sciences, 1:45-49.

Kurtzman, R.H. Jr. (1978). Coprinus fimetarius. In: The biology and cultivation of edible mushrooms (Eds. S.T. Chang and W.A. Hayes), Academic Press Inc., London: 393-406.

Manzi, P., Aguzzi, A. and Pizzoferrato, L. (2000). Beta-gulcans in edible mushrooms widely consumed in Italy. Food Chem, 73(3):321-325.

McKenny, M. (1971): The savory wild mushroom. University of Washington press, U.S.A.

McKnight, K.H. and McKnight, V.B. (1987). Mushrooms. A field guide to mushrooms North America, Houghton Mifflin Company, Boston.

Nepal, M, Gupta, V.N.P., Vetaas, O.R. and Chaudhari, R.P. (1999). Utilization of plant resources of Makalu-Barun buffer zone, eastern Nepal used by Rais and the Sherpa communities. pp: 1359-1370 In: Proceedings of III National conference on science and Technology. March 811, 1999.

Pandey, N. (2006). Preliminary study on the mushrooms diversity of Langtang National Park. A report submitted to the Department of National park and Wildlife Conservation, Babarmahal, Kathmandu. pp19.

Pandey, N and Budhathoki, U. (2007a). Protein determination through Bradford's method of Nepalese mushroom. Scientific world, 5(5):85-88. 
Pandey N and Budhathoki, U. (2007b). Status of ethnomycology in Nepal. In: Mycological research and mushroom production in Nepal:53-60.

Purukayastha, R.P. and Chandra, A. (1985). Manual of Indian Edible Mushrooms. Jagendra Book Agency, New Delhi, India.

Rai, R.D. (1995). Nutritional and medicinal values of mushrooms. In: Advances in Horticulture Vol.13: Mushroom (Eds. K.L Chadh, and S. R. Sharma), Malhotra Publishing House, New Delhi:537-551.

Rana, P. and Giri, A. (2006). Diversity of mushroom in Sagarmatha National Park, Nepal. Banko Janakari (A Nepalese Journal of forestry), 16(2):17-24.

Sacherer J. (1979). The high altitude ethnobotany of the Rowaling Sherpas: A contribution of Nepalese studies. Journal of Research in Central Nepal Studies, 6(2):46-64.

Svreck, M. (1975). A colour guide to familiar mushrooms. Octopus book Comp.

Sharma, N. (2003). Medicinal uses of macrofungi. Ethnobotany, 15:97-99.

Singh, S. C. and Nisha. (1973). Experimental cultivation of Pleurotus in Nepal. Jour. Trib. Univ, 8:81-85.

Tullons, R.E. \& Bhandary, H.R. (1992). Amanita chepangiana: A new species from Nepal. Mycotaxon, XL111:25-31.

Wong, W.C. and Cheung, P.C.K. (2001). Food and nutritional sciences programme. The Chinese University of Hong Kong, Shatin, New Territories, Hong Kong, China.

Yang, Z.L. (2002). On wild mushroom resources and their utilization in Yunnan province, southwestern China. Journal of Natural Resources, 17:464-469

\section{Author's Address}

${ }^{1}$ Anjana Giri and ${ }^{2}$ Prabina Rana

Nepal Academy of Science and Technology (NAST)

P.O.Box 3323, Khumaltar, Nepal

email: anjanagiri@hotmail.com

prabinar@hotmail.com 
TABLE 1. Scientific names, family, local names, locality and uses of wild mushrooms.

\begin{tabular}{|c|c|c|c|c|}
\hline $\begin{array}{l}\text { S. } \\
\text { no }\end{array}$ & Scientific Name & Family & Local Names & Locality (forest) \\
\hline 1 & $\begin{array}{l}\text { Amanita hemibapha } \\
\text { (Berk. \& Br.) Sacc. }\end{array}$ & Amanitaceae & Rato anda chyau & Muse ( Lukla) \\
\hline 2 & $\begin{array}{l}\text { Amanita vaginata } \\
\text { (Bull.:Fr.) Vitt. }\end{array}$ & Amanitaceae & Seto anda chyau & Muse (Lukla) \\
\hline 3 & Amanita sp. & Amanitaceae & Sano anda chyau & Muse (Lukla) \\
\hline 4 & $\begin{array}{l}\text { Armillariella mellea } \\
\text { (Vahl.:Fr.) Kummer }\end{array}$ & Tricholomataceae & Chiple chyau & $\begin{array}{l}\text { Muse (Lukla), Phurte, Jamikhiau } \\
\text { (Khumjung) }\end{array}$ \\
\hline 5 & $\begin{array}{l}\text { Auricularia } \\
\text { polytricha (Mont.) } \\
\text { Sacc }\end{array}$ & Auriculariaceae & Durkho chyau & $\begin{array}{l}\text { Chire (Kunde), Deboche, Omakha } \\
\text { (Pangboche) }\end{array}$ \\
\hline 6 & Boletus sp. & Boletaceae & $\begin{array}{l}\text { Fhe shyamo/Muse } \\
\text { chyau }\end{array}$ & $\begin{array}{l}\text { Chire (Kunde), Jamikhiau (Khumjung) } \\
\text { Deboche, and Omakha (Pangboche) }\end{array}$ \\
\hline 7 & $\begin{array}{l}\text { Boletus edulis Bull.: } \\
\text { Fr. Steinpliz }\end{array}$ & Boletaceae & Pani chyau & Muse (Lukla) \\
\hline 8 & Boletus sp. & Boletaceae & Rato martip & $\begin{array}{l}\text { Muse (Lukla), Chire (Kunde), } \\
\text { Jamikiau (Khumjung) Deboche, and } \\
\text { Omakha (Pangboche }\end{array}$ \\
\hline 9 & Boletus auripes Peck & Boletaceae & Seto martip & Muse (Lukla) Phurte (Namche) \\
\hline 10 & $\begin{array}{l}\text { Boletus pulverulentus } \\
\text { Opat. }\end{array}$ & Boletaceae & Kalo martip & Muse(Lukla) \\
\hline 11 & $\begin{array}{l}\text { Cantharella cibarius } \\
\text { (Fr.: Fr.) Fr. }\end{array}$ & Cantharellaceae & Kujir (pothi) & $\begin{array}{l}\text { Chire (Kunde), Jami khiau } \\
\text { (Khumjung) Deboche }\end{array}$ \\
\hline 12 & $\begin{array}{l}\text { Chroogomphus } \\
\text { tomentosus (Murr.) } \\
\text { O.K.Miller }\end{array}$ & Gomphidiceae & Kujir (Keta) & $\begin{array}{l}\text { Chire (Kunde), Jamikhiau (Khumjung) } \\
\text { Deboche, Omakha (Pangboche) }\end{array}$ \\
\hline 13 & $\begin{array}{l}\text { Clavulina cinerea } \\
\text { (Bull.: Fr.) Schroet. }\end{array}$ & Clavulinaceae & Che shyamo & Phurte (Namche) \\
\hline 14 & $\begin{array}{l}\text { Rhodocollybia } \\
\text { butyraceae (Bull.: } \\
\text { Fr.) Lennox }\end{array}$ & Marasmiaceae & Karshya (Pothi) & Phurte (Namche) \\
\hline 15 & $\begin{array}{l}\text { Gomphus clavatus } \\
\text { (Pers. : Fr.) S. F. } \\
\text { Gray }\end{array}$ & Gomphaceae & Ee- shyamo & $\begin{array}{l}\text { Phurte ( Namche) Chire (Kunde), } \\
\text { Jamikhiau (Khumjung) }\end{array}$ \\
\hline 16 & $\begin{array}{l}\text { Gomphus floccosus } \\
\text { (Schw.) Singer var } \\
\text { floccosus }\end{array}$ & Gomphaceae & Khumbhe chyau & $\begin{array}{l}\text { Phurte (Namche) Chire (Kunde), } \\
\text { Jamikhiau (Khumjung) Deboche, }\end{array}$ \\
\hline 17 & $\begin{array}{l}\text { Hydnum repandum } \\
\text { L. : Fr. }\end{array}$ & Hydnaceae & $\begin{array}{l}\text { La shyamo/kasturi } \\
\text { chyau }\end{array}$ & Jamikhiau ( Khumjung) \\
\hline 18 & Hygrophorous sp. & Hygrophoraceae & Petok shyamo & Phurte (Namche) \\
\hline 19 & $\begin{array}{l}\text { Laccaria laccata } \\
\text { ( Scop.: Fr.) Cooke }\end{array}$ & Tricholomataceae & Chinduk shyamo & Jamikhiau \\
\hline 20 & Leccinum sp. & Boletaceae & Omi shyamo & Chire (Kunde), Jamikhiau (Khumjung) \\
\hline 21 & $\begin{array}{l}\text { Ramaria flava (Sch.: } \\
\text { Fr.) Quel. }\end{array}$ & Ramariaceae & Che shyamo & $\begin{array}{l}\text { Phurte (Namche) Chire (Kunde), } \\
\text { Jamikhiau (Khumjung) Deboche. }\end{array}$ \\
\hline 22 & $\begin{array}{l}\text { Ramaria botrytis } \\
\text { (Pers.:Fr.) Ricken }\end{array}$ & Ramariaceae & Che shyamo & Phurte (Namche), Deboche \\
\hline 23 & $\begin{array}{l}\text { Russula metachroa } \\
\text { Hongo }\end{array}$ & Russulaceae & Pakar shyamo & $\begin{array}{l}\text { Phurte (Namche), Jamikiau } \\
\text { (Khumjung) }\end{array}$ \\
\hline 24 & $\begin{array}{l}\text { Hypholoma } \\
\text { capnoides (Fr.) } \\
\text { Kumm. }\end{array}$ & Strophariaceae & Taktale & Phurte (Namche) \\
\hline 25 & $\begin{array}{l}\text { Paxillus involutus } \\
\text { (batsch: Fr.)Fr. }\end{array}$ & Paxillaceae & Dyangba shyamo & Jamikhiau (Khumjung) \\
\hline 26 & $\begin{array}{l}\text { Tylopilus eximus } \\
\text { (Peck) Sing }\end{array}$ & Boletaceae & $\begin{array}{l}\text { Kyakti / Jip } \\
\text { chyambo }\end{array}$ & $\begin{array}{l}\text { Chire (Khunde), Jamikhiau } \\
\text { (Khumjung), Deboche }\end{array}$ \\
\hline
\end{tabular}


Table 2. Proximate analysis of mushrooms collected from the study area.

\begin{tabular}{|l|l|l|l|l|l|l|l|}
\hline $\begin{array}{l}\text { S. } \\
\text { N }\end{array}$ & $\begin{array}{l}\text { Mushroom } \\
\text { species }\end{array}$ & $\begin{array}{l}\text { Crude } \\
\text { Protein } \\
(\%)\end{array}$ & $\begin{array}{l}\text { Crude } \\
\text { Fat } \\
(\%)\end{array}$ & $\begin{array}{l}\text { Moisture } \\
(\%)\end{array}$ & Ash & $\begin{array}{l}\text { Carbo- } \\
\text { hydrate } \\
(\%)\end{array}$ & $\begin{array}{l}\text { Crude } \\
\text { Fibre } \\
(\%)\end{array}$ \\
\hline 1 & Ramaria flava & $\mathbf{2 8 . 3 2 * *}$ & 1.35 & 10.88 & 16.53 & 42.96 & 8.85 \\
\hline 2 & Paxillus involutus & 16.46 & 3.37 & 10.27 & $\mathbf{2 8 . 8 8 * *}$ & 41.02 & 12.55 \\
\hline 3 & Gomphus clavatus & 22.68 & 0.97 & 10.86 & 18.44 & 47.05 & 8.69 \\
\hline 4 & Leccinum sp. & 21.33 & 0.89 & 10.73 & 18.06 & 48.99 & 10.17 \\
\hline 5 & Ramaria botrytis & 16.96 & $\mathbf{0 . 3 9 *}$ & 10.15 & 23.5 & 53.32 & 7.97 \\
\hline 6 & Hygrophorous sp. & 22.97 & 1.53 & $\mathbf{1 1 . 9 5 * *}$ & 19.18 & 40.05 & $\mathbf{7 . 7 3}^{*}$ \\
\hline 7 & Gomphus floccosus & 20.97 & 1.89 & $\mathbf{8 . 3 0}$ & 16.36 & 40.35 & 14.02 \\
\hline 8 & Tylopilus eximus & 25.89 & 1.78 & 11.46 & 24.36 & 36.51 & $\mathbf{1 9 . 8 4 * *}$ \\
\hline 9 & $\begin{array}{l}\text { Chroogomphus } \\
\text { tomentosus }\end{array}$ & $\mathbf{1 1 . 8 4 *}$ & 2.42 & 9.69 & $\mathbf{1 3 . 4 2} *$ & $\mathbf{6 2 . 6 3} * *$ & 8.78 \\
\hline 10 & Amanita hemibapha & 25.87 & $\mathbf{6 . 4 8 * *}$ & 10.23 & 26.4 & $\mathbf{3 1 . 0 2 *}$ & 13.37 \\
\hline 11 & Boletus sp. & 27.75 & 1.99 & 9.40 & 24.42 & 36.44 & 19.05 \\
\hline
\end{tabular}

* Lowest value

** Highest value

Table 3. Mineral analysis of mushrooms collected from the study area.

\begin{tabular}{|l|l|l|l|l|}
\hline $\begin{array}{l}\text { S. } \\
\text { N }\end{array}$ & $\begin{array}{l}\text { Sushroom } \\
\text { Species }\end{array}$ & $\begin{array}{l}\text { Calcium } \\
(\mathrm{Ca}) \\
(\mathrm{mg} / 100 \mathrm{gm})\end{array}$ & $\begin{array}{l}\text { Phosphorous } \\
(\mathrm{P}) \\
(\mathrm{mg} / 100 \mathrm{gm})\end{array}$ & $\begin{array}{l}\text { Iron } \\
(\mathrm{Fe}) \\
(\mathrm{mg} / 100 \mathrm{gm})\end{array}$ \\
\hline 1 & Ramaria flava & 6.66 & $\mathbf{6 2 . 5 1 *}^{*}$ & 4.07 \\
\hline 2 & Paxillus involutus & 5.40 & $\mathbf{9 4 4}^{* *}$ & 6.16 \\
\hline 3 & Gomphus clavatus & 26.22 & 389.49 & 25.37 \\
\hline 4 & Leccinum sp. & 6.10 & 480 & $\mathbf{0 . 5 7 6 ^ { * }}$ \\
\hline 5 & Ramaria botrytis & 6.30 & 441 & 6.21 \\
\hline 6 & Hygrophorous sp. & 6.17 & 649.37 & 13.23 \\
\hline 7 & Gomphus floccosus & $\mathbf{3 3 . 0 9 * *}$ & 518.9 & 54.56 \\
\hline 8 & Tylopilus eximus & 2.92 & 359 & 0.93 \\
\hline 9 & Chroogomphus tomentosus & 4.01 & 264 & 2.81 \\
\hline 10 & Amanita hemibapha & 20.09 & 721.75 & $\mathbf{3 0 7 . 2 6 * *}$ \\
\hline 11 & Boletus sp. & $\mathbf{1 . 8 2 *}$ & 163.77 & 10.66 \\
\hline
\end{tabular}

\section{* Lowest value}

** Highest value

Table 4. Crude protein, carbohydrate, fat, fibre, calcium (C), phosphorous (P) and Iron (Fe) content of some cultivated edible mushrooms.

\begin{tabular}{|l|l|l|l|l|l|l|l|}
\hline Mushrooms & $\begin{array}{l}\text { Protein } \\
(\%)\end{array}$ & $\begin{array}{l}\text { Carbohydrat } \\
\mathrm{e}(\%)\end{array}$ & $\begin{array}{l}\text { Fat } \\
(\%)\end{array}$ & $\begin{array}{l}\text { Fibre } \\
(\%)\end{array}$ & $\begin{array}{l}\text { Ca } \\
\mathrm{mg} / 100 \mathrm{gm})\end{array}$ & $\begin{array}{l}\text { Fe } \\
(\mathrm{mg} / 100 \mathrm{gm})\end{array}$ & $\begin{array}{l}\mathrm{P} \\
(\mathrm{mg} / 100 \mathrm{gm})\end{array}$ \\
\hline $\begin{array}{l}\text { Agaricus } \\
\text { bisporous }\end{array}$ & 26.3 & 49.5 & 1.8 & $8-10.4$ & 23 & $0.2-19.0$ & $790-1425$ \\
\hline $\begin{array}{l}\text { Pleurotus } \\
\text { ostrateus }\end{array}$ & 10.5 & 74.3 & 1.6 & $7.5-8.7$ & 33 & 15.2 & 1348 \\
\hline $\begin{array}{l}\text { Volvariella } \\
\text { volvacea }\end{array}$ & 29.5 & 40.0 & 5.7 & $4.4-13.4$ & 35 & 6.0 & $978-1337$ \\
\hline Lentinula edodes & 17.5 & 59.5 & 8.0 & $7.3-8.0$ & 98 & 8.5 & 476 \\
\hline
\end{tabular}

Source: Crisan \& Sands (1978) and Li \& Chang (1982) 


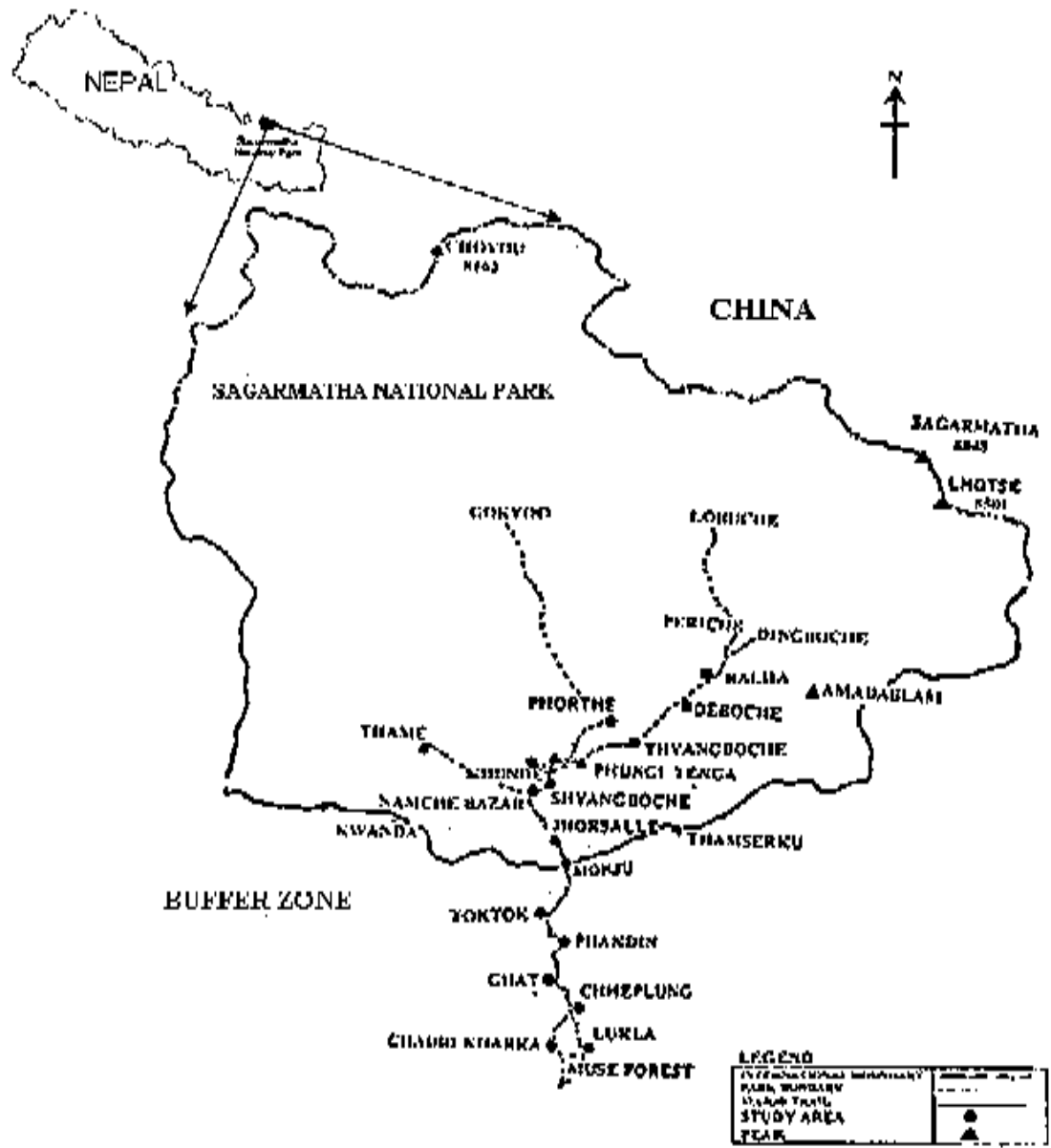

TICAURT: 1. Map of the stody area 